\title{
Article \\ The Source Value of Arabic Typikon-Manuscripts as Testimonials for the Byzantinization of the Melkites
}

\author{
Martin Lüstraeten
}

Citation: Lüstraeten, Martin. 2021. The Source Value of Arabic Typikon-Manuscripts as Testimonials for the Byzantinization of the Melkites. Religions 12: 931. https://doi.org/10.3390/rel12110931

Academic Editor: Stig R. Frøyshov

Received: 31 August 2021

Accepted: 15 October 2021

Published: 27 October 2021

Publisher's Note: MDPI stays neutral with regard to jurisdictional claims in published maps and institutional affiliations.

Copyright: (C) 2021 by the author. Licensee MDPI, Basel, Switzerland. This article is an open access article distributed under the terms and conditions of the Creative Commons Attribution (CC BY) license (https:// creativecommons.org/licenses/by/ $4.0 /)$.
Katholisch-Theologische Fakultät, Seminar für Praktische Theologie, Abteilung Liturgiewissenschaft und Homiletik, Johannes Gutenberg-Universität Mainz, 55099 Mainz, Germany; luestraeten@uni-mainz.de

\begin{abstract}
With the expansion of Islam, the patriarchates of Antioch, Jerusalem, and Alexandria were divided from the Byzantine Empire. The Orthodox Christians there still defined themselves as Byzantine Orthodox and began to adapt their liturgical customs by adopting Byzantine liturgical books. When Greek was not understood any longer, they began to translate and copy their liturgical books, thereby creating their own branch of tradition, which is marked by multilingualism, reception of their own Bible tradition as well as the exclusion of "neo-martyrs" from their calendar of saints.
\end{abstract}

Keywords: Arabic Christianity; Byzantine Rite; liturgical reform; liturgy; manuscript; Melkite; RūmOrthodox; Syriac Christianity; Typikon

\section{Introduction}

After the Council of Chalcedon (451 CE), the Christians in the patriarchates of Antioch, Jerusalem, and Alexandria were divided into a pre-Chalcedonese so-called "Miaphysite" group and the "Chalcedonese" group, which was also designated as "Melkite". With this division, the impact of Byzantium on the worship traditions of the Melkites grew (Nasrallah 1987, p. 156).

The designation as "Melkite" is itself troubling. Apparently, the term was purely pejorative (Treiger 2014, p. 8) and not used as a self-designation before the 15th century. The Melkites simply felt that, being Orthodox and regarding the hierarchy of the church, there was no differentiation between Orthodox and Melkite (Galadza and van Vogelpoel 2019, pp. 36-37). It rather seems that the designation points to the language; in this case, we would speak of the "Melkites" as Arabic-speaking orthodox Christians (Galadza 2018, p. 81), and it seems that this designation is projected back to the roots of Orthodox Christians in the patriarchates of Alexandria, Antioch, and Jerusalem.

With the rise of Islam and the Arabic conquests in the early 7th century, the Melkites were cut off from the Byzantine Empire and lost the support of the Emperor, so they had to define their own identity in contrast to the other Christian denominations who shared the same juridical status. They did so by relying on the worship tradition of Byzantium, and by adopting their own rites and particular traditions to the Byzantine Rite by taking Byzantine liturgical books and as soon as they were not able to speak Greek any longer, by translating those liturgical books into Arabic. This process of Byzantinization was a silent and slow process, taking place "gradually and locally" (Galadza and van Vogelpoel 2019, p. 39). It ended with the Melkite patriarch Malātiyūs Karma (d. 1634) deciding to translate all the Byzantine liturgical books at once and print them. For this purpose, he took the existing translations of the manuscript tradition and corrected them against the circulating Greek Byzantine liturgical books, leading to plain translations without specific Melkite traditions.

Since there is no fixed date for the process of Byzantinization with respect to how and where it began, I investigated the Arabic manuscript tradition of the Typikon.

In what follows, I will take up the comparative analysis of the existing Arabic Typikon manuscripts that I undertook for my dissertation project and provide additional data that 
result from important studies that have been published recently (e.g., Galadza 2018; Penn 2015; Sahner 2018; Tannous 2018). I will start with a brief presentation of the manuscripts, focusing on the relationships between them, since there are families that can be identified that seem to be independent of each other. This is followed by brief reflections on those relationships. The third chapter consists of observations regarding certain aspects of the worship as regulated in the Typikon manuscripts that demonstrate the process of formation of identity as Byzantine Christians on the one hand and Arabic Christians on the other hand: the question of the use of Arabic in worship, the question of quotations from the Bible and therefore the acquaintance with the existing versions of the Bible, and the question of the calendar of saints.

\section{The Arabic Typikon Manuscripts}

\subsection{Short Presentation of the Arabic Typikon Manuscripts}

\subsubsection{Overview}

The manuscripts of Arabic Typikon translations that I have compared in my research have been identified in Joseph Nasrallah's seven-volume work "Histoire du mouvement littéraire dans l'Église Melchite du Ve au XXe siècle" (Nasrallah 1979, 1981, 1983, 1987, 1989, 1996; Nasrallah and Haddad 2016). There are, however, further manuscripts among the Sinai New Finds, among them Sinai ar. NF 65, which consists of only 24 folios giving an index of feasts for the years 6776 and $6777 \mathrm{AM}(1268$ and $1269 \mathrm{CE})$ and a poem to the name of God (Meïmarēs 1985, p. 59), as well as Sinai ar. NF 83, a corroded fragment of a codex that seems to transmit liturgical instructions (Meïmarēs 1985, p. 62).

The Typikon manuscripts are (in chronological order):

- $\quad$ Sinai ar. 265

- Paul Sbath 73

- Sinai ar. 266

- Sinai ar. 267

- Sinai ar. 264

- Saidnāyā 107

- Mār 'Aliyās Šwayyā 34

Like almost all Christian Arabic liturgical manuscripts, these Typikon manuscripts are translations from Syriac or Greek, but these translations developed their own history: existing translations were taken and corrected or further developed, and by this, the Syriac or Greek original source was blurred. Due to misunderstandings of the original text, new terms and expressions were created and received (Ghoneim 2010, pp. 45-46). Thus, the Arabic Typikon manuscripts build their own branch of tradition.

\subsubsection{Sin. ar. 265}

Sinai ar. 265 is a Typikon, presumably from the thirteenth century (following the catalogue, Kāmil 1951, p. 33), consisting of 192 leaves of paper. The leaves have been numbered by a younger scribal hand, and among them are the remains of the torn-out leaf no. 150, which must have been torn out before the entry of the page numbers. Each page consists of 13 to 14 lines, and the alphabets used are Arabic and Greek. The manuscript is, furthermore, highly decorated with patterns, calligraphy, and miniatures. It is a beautiful manuscript: the line breaks are even, sections are marked by ornamentation, subheadings usually cover the full width of a page, and the ink colors are black and red. One remarkable aspect allows further conclusions to be drawn about the preparation of the manuscript: fol. $54 \mathrm{~b}$ is struck out and is very similar to fol. $112 \mathrm{~b}$, and missing words in lines 7 and 9 caused a shift of the text, which is maybe a hint that it is a grubby copy of an already existing Arabic manuscript rather than the sign of an original translation.

The colophon on fol. $149 \mathrm{~b}$ is as follows:

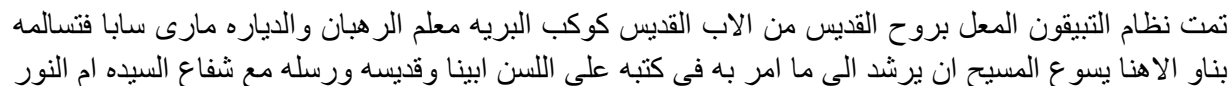




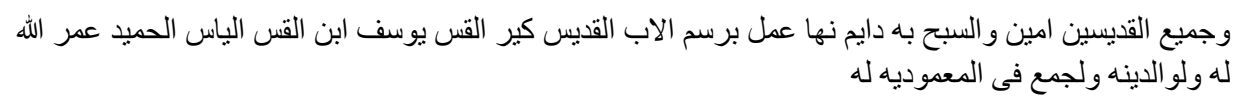

I completed the system of the Typikon, the work in the Holy Spirit, of the holy father, the star of the desert, the teacher of the monks and the monasteries, Māri Sābā. And it was given to him by the son of our God, Jesus the Messiah, that he guides to what he commanded with it in his scripture, through the tongue of our father and his saints and his apostles with the intercession of our Lady, the mother of the light, and all the saints. Amen. And glory to him forever. End of the works by order of the holy father, Kīr, the presbyter, Yūsuf, son of the presbyter 'Aliyās, the praiseworthy. May God grant a long life to him and to his parents and to the community connected to him by baptism. ${ }^{1}$

There is no hint of when and how the manuscript came to the Sinai monastery, its place of preservation today, or what it was used for. On the one hand, there are only a few traces of use, but on the other hand, there are hints of a direct liturgical purpose, since the Typikon is collated with a collection of Arabic translations of sayings of fathers and a collection of Greek apolytikia.

Sabas and his lavra are referred to in the title of the manuscript, which is quite typical for the Sabaitic Typikon:

$$
\text { صنام ترتيب الكنايسي المستقيح ر ايها المسما بلغه اليونانيه تبيقون اي معلم الكنايس ومدير ها المنسوب الى الاب سابا }
$$

System of the orthodox ecclesial order, which is called in the Greek language Tibiquin, i.e., the teacher of the churches and her directory which is attributed to the father, Sabas, the founder of the lavra, the god-bearing.

\subsubsection{Sbath 73}

The manuscript Sbath 73 is taken from the collection of Paul Sbath, former Syrian priest in Aleppo, which is now kept in Rome at the Vatican Library. The catalog of Paul Sbath identifies this manuscript as a Typikon in Arabic and Syriac from the thirteenth century (Sbath 1928, p. 51). However, comparing the contents shows that the manuscript seems to be younger than Sinai ar. 267 (discussed below), so it is likely from the fourteenth century (Lüstraeten 2017, p. 141).

Unfortunately, the manuscript is fragmented and the name of the scribe and the title of the manuscript are missing. The manuscript consists of 242 leaves of paper with differing numbers of lines of script, and for each section there is a quire mark on the upper left edge in the form of an Arabic ordinal number written in full, following which the manuscript starts with the second section of about 16 pages and the last section or the last two sections are also missing.

The manuscript is written in Arabic and Syriac, and most of the liturgical texts as well as the references to the Bible have been preserved in Syriac.

What is striking are the numerous cancellations and amendments, which appear to be testimonials for extensive use. Thus, the manuscript seems to have been in poor condition already from its beginning.

\subsubsection{Sinai ar. 266}

Sinai ar. 266 is enigmatic. The title of the manuscript gives no hint to the Sabas monastery:

$$
\text { فصل مختصر من التبيقون يعرف به اطروباريات العياد علي دور السنة بتمامه وكماله }
$$

Abridged section of the Tibīqūn to become acquainted with the Trūbāriyāt of the feasts in the course of the year in its entirety and completeness.

In fact, this manuscript is not a Typikon but a calendar of feasts with full Arabic translations of the respective apolytikia. The manuscript is collated with a table for the computation of Easter and a lectionary of the eleven resurrection Gospels. Since the first entry in 
the table is for the year $6830 \mathrm{Am}$ and gives 12 April for Easter, which can be identified with the year $1322 \mathrm{CE}$, Murad Kāmil identified this as the year of composition (Lüstraeten: 143). There is no colophon, no entry regarding the owner or the purchase of the manuscript, or anything else which would allow conclusions to its origins.

\subsubsection{Sin. ar. 267}

The manuscript Sinai ar. 267 is again a Typikon in Arabic and Syriac and is dependent on the manuscript Saidnāyā 107. Kāmil (1951, p. 34) dates this manuscript to the year 1325, Nasrallah (1981, p. 150) states that it was written before 1326, but 'Azīz Atịya (1970, p. 496) gives the year 1345. This discrepancy is caused by the colophon on fol. 353ab, which states:

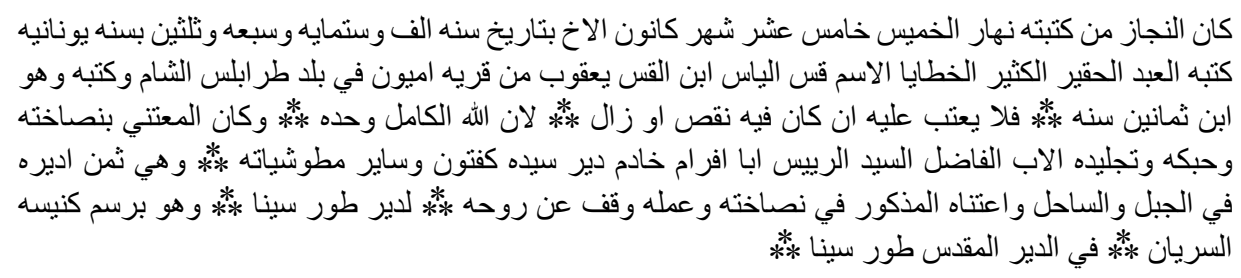

And the completion of this book was on Thursday, the fifteenth of the second Kanūn of the year one thousand six hundred and thirty-seven in the Greek year. It was written by the humble and manifold sinful servant with the name: presbyter 'Aliyās, son of the presbyter Ya 'qūb, from the village of 'Amiyūn in the land of Tripoli of Syria. And he wrote it as a man of eighty years. So don't admonish if there is an omission or an amendment, because 'Allāh is perfectly one. And the one who cared for its copy, its binding and its cover, was the exceptional father, the presider, 'Abā 'Afrām, servant of the monastery of the Lady of Kaftūn and the rest of its metochies. And those are eight monasteries in the mountains and at the shore. And the abovementioned took pains to preserve its spirit in the copy and his work for the monastery of Mount Sinai.

The date can only relate to the system of the Seleucid Era (also called "anno Graecorum"), which would not have been in use in that time anymore, except for some Syriac chroniclers. There are different systems with different beginnings of the year, so a precise transfer to our calendar is not possible; the year would be 1326 or 1327, suggesting Nasrallah's dating is correct.

The colophon further identifies the writer as coming from 'Amiyūn and the purchaser to come from the monastery of Our Lady at Kaftūn, which is very close to 'Amiyūn. This monastery was either a bi-confessional monastery or a double monastery for two confessions in the thirteenth century, where Melkite and Maronite monks lived close to each other (Mouawad 2002, p. 95).

On the flyleaf preceding the first page, there is a notice of purchase, indicating that this manuscript was given "to the church of Our Lady for the group of Syrians," which could possibly be identified with the Syriac congregation of the monastery Mt. Sinai, where it is kept today.

The title of the manuscript refers, of course, to the lavra of St Sabas:

$$
\text { [نكتب] ترتيبً كناسياً ونظامً بيعياً مسما بلغه اليناني تبيكن منسوبَ الي سيق ابينا البار و المتوشح بالله سابا }
$$

We write the ecclesial order and the churchly system, called in the Greek language Tibīkun, attributed to the lavra of our father, the blessed god-bearer Sābā.

The script is untypical: to help the reader, there are marginal notes with information on the content of each double page-it seems that the Syriac script and the Arabic script were not written at the same time. The manuscript is in a good condition and bears only few traces of use. 


\subsubsection{Sin. ar. 264}

The Typikon Sinai ar. 264 was - according to Murād Kāmil-written in 1336, but this is a strange date regarding the several steps of redaction, of which the redaction of 1336 was neither the first nor the last: the original manuscript was a Greek manuscript, written by the monk Hesychios of the monastery Mar Saba, who finished his work on 22 April $6695 \mathrm{AM}$, which is $1187 \mathrm{CE}$. He gave that manuscript to the church of the Forty Martyrs in Harat ar-Rūm (part of today's Cairo). The colophon takes this as a point of departure for its strong emphasis on the ties to the Sabas monastery, as is stated on fol. 204b:

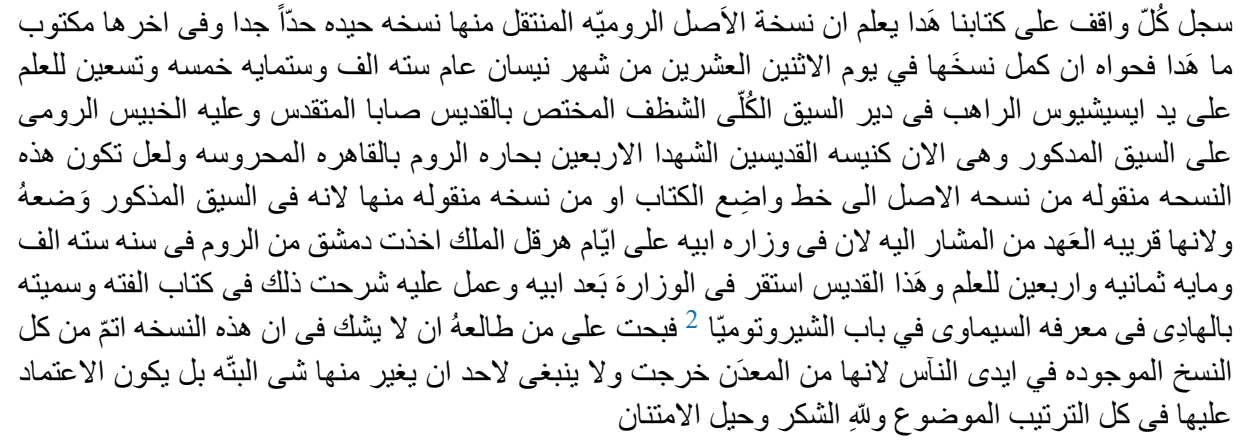

Everyone who is interested in this our book is informed that the translated Roman [=Byzantine] original copy was copied till the end. And at its completion it is written that its sense and its copy were completed on the twenty-second day of the month Nīsān [= April] of the year six thousand six hundred ninetyfive of the world [=1187 CE] by the hands of 'İsišiyūs [=Hesychios], the monk, in the monastery of the lavra of great discomfort, the one dedicated to the holy Sạ̄bā, the Sanctified. And he is a Roman [=Greek] hermit according to the abovementioned lavra. And it is for the church of the Forty Martyrs at Hārat ar-Rūm at Cairo. And this copy was translated from the original copy to the script of the writer of that book or from a translated copy, so that in the above-mentioned lavra it was compiled. And so it is closely adhered to because it was in the scriptorium of our father in the days of Haraqal [=Herakleios], the king, when Damascus was taken from Rome, in the year six thousand one hundred forty-eight of the world $[=640 \mathrm{CE}]$. And this saint settled in the scriptorium after his father and worked on it. This was explained in a book that he composed and named "Guidance to the teaching about the heavenly things" in the chapter "Aš-širotoniya" [=Cheirotonia]. And he investigated about him, who perused it, so that there is no doubt that this copy was finished before all [other] copies which can be found in the hands of men, so this is the original which was published. And it is not desired that anyone changes anything, but there should be reliance on it in all the regulations that are given. And thanks be to God and gratitude to his power.

The translation into Arabic was finished on Wednesday, 28 February 6816 AM, given in Greek numbers, which is the year 1308 сE. The first appendix was added on Tuesday, 5 December $6844 \mathrm{Am}$, which is identified with the seventeenth day of Rabí- II $736 \mathrm{AH}$ and corresponds to the year 1335 св. The author of that first appendix is Abu l-Fath Qustantịn Ibn Abì l-Ma àlī Ibn Abī l-Fath, apparently a monk.

The second appendix is not identified. The third appendix was added on Friday, 2 April 7082 AM, which corresponds to the year $1574 \mathrm{cE}$, by a monk named Pachomios. This shows that the manuscript was in use for more than two hundred years.

The manuscript starts with a long doxology and a poem and then turns to explaining the purpose of a Typikon, after which it continues with the title:

$$
\text { التيبيكون المشتمل على الرسوم البيعيّه }
$$

The Typikon, comprising the orders of the church 
Neither Sabas nor his lavra is mentioned. However, as shown, the colophon claims a Sabaitic manuscript as a model.

\subsubsection{Saidnāyā 107}

The manuscript Saidnāyā 107 appears to be a copy of Sinai ar. 267. The title is thus almost the same:

$$
\text { [نكتب] نظامً بيعياً وترتيب كناسياً مسما بلغه اليناني تبيكن منسوبَ الي سيق ابينا البار المتوشح بالله سابا }
$$

We write the churchly system and the ecclesial order, called in the Greek language Tibīkun, attributed to the lavra of our father, the blessed god-bearer Sābā.

The colophon on fol. 304b-305a gives some information on the way this manuscript has traveled:

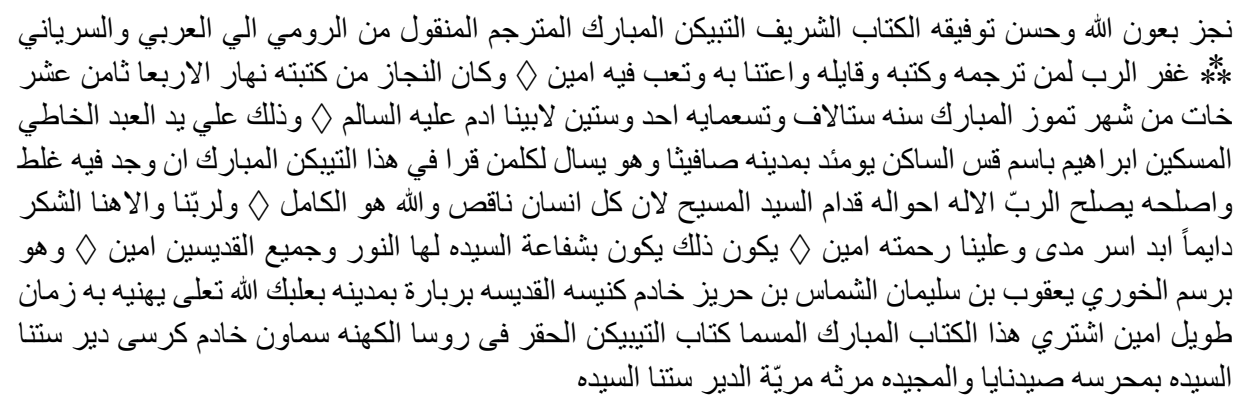

Executed with the aid of God the most high, this noble book is in accordance with the blessed Tibikun, translated from Roman [=Greek] to Arabic and Syriac. The Lord guarded him who translated it, copied it, and compiled it and who cared for it and made efforts with it. Amen. And the execution of his book took eightyfour days. It was completed on Wednesday, the eighteenth of the blessed month Tammūz of the year six thousand nine hundred sixty-one since the creation of Adam - peace be on him [typical Islamic formula for the designation of saints] [=1453 CE?]. And this by the hand of the fallible and miserable servant 'Ibrāhīm by name, henceforth priest at the town of Sạfitā. And he asks everyone who reads in this blessed Tibikun, if he finds mistakes or better things, to correct it. The Lord God be kind to his years, because before the Lord, the Messiah, every human is peccable and God is the perfect one. And to our Lord and our God be thanks for ever and ever and upon us his mercy. Amen. And this be with the intercession of our Lady, to her be the light, and of all saints. Amen. And it was [written] by the command of the chorbishop Ya 'qūb, son of Sulaymān, the deacon, son of Hāriz, servant of the church of the holy Barabra in the town of Ba'albak. God, the most high, may grant him a long life. Amen. This blessed book, which is called book of the Tībikun was purchased by the humble among the directors of the priesthood, Simā ūn [=Symeon], servant of the chair of the monastery of our Lady in the town wall of Saydnāyā and of the blessed Marta Marya of the monastery of our Lady.

Thus, the manuscript was completed on Wednesday, 18 July 6961 AM, which corresponds to the year $1453 \mathrm{CE}$, and it was written by 'Ibrahīm, presbyter at the town of Sạfitā. The codex was commissioned by the bishop Ya 'qūb 'Ibn Sulaymān 'Ibn Hậ̄z, rector of the church of St Barbara at Ba albek. A partially illegible notice on the last page gives the information that a person named Simā' ūn purchased it for the monastery of Saidnāyā, of which he was the abbot. Another notice gives the date of Wednesday, 26 July 7073 AM, which corresponds to the year $1564 \mathrm{cE}$, for a purchase-maybe the purchase for the monastery of Saidnāyā since the manuscript was kept there. 


\subsubsection{Mār 'Aliyās Šwayyā 34}

The manuscript Mār 'Aliyās Šwayyā 34 bears the following title:

$$
\text { التيبيكون المشتمل على الرسوم البيعيّه }
$$

The Tìbīkun, comprising the orders of the church

It is the same title as Sinai ar. 264 and it is obviously a copy. On fol. 23b, it is written that the manuscript was written in two parts: the description of the agrypnia was taken from an earlier translation and the second part was written by Sābā bi 'Ism lā bi-l-fa 1 talmī al-' Ab al-matrān Yū' àkīm al-Ladaqīy at the monastery of Dūmā. This work was finished on Thursday, 6 March 7103 Am, which corresponds to the year 1595 cE. The colophon mentions further Sābā bi 'ism šammās 'ibn tadrus mu raf bi 'Ibn al Hawrānīy from Beirut as copyist, who made this copy at the monastery of St John the Baptist at Dūmā in the region of Batrūn. A notice on fol. 211b says that the manuscript was given to the monastery of Mār 'Aliyās in Šwayyā and the reception was confirmed on fol. $1 \mathrm{~b}$ by Bishop Yuhannā from Ma alūlā-unfortunately, he does not provide a date. The manuscripts correspond mostly word-by-word to Sinai arabicus 264, but the content of the appendices was integrated into the corpus.

\subsection{Monasteries as the Contributors to the Process of Arabization and Byzantinization}

All the Arabic Typikon manuscripts and most of the Arabic liturgical manuscripts come from monasteries. This is to be expected since the monasteries were consulted as scriptoria to copy books and since they possessed repositories for huge amounts of books. Palestinian monastic life was especially multifaceted and brought together monks from different cultures and languages, so the monasteries there were international (Hirschfeld 2006, pp. 401-2). Thus, there were different languages spoken, and if the communities were large enough, it could be arranged that they held the services in their own language (Taft 2010, pp. 168-69), which is already attested for the time of the founding of the lavra of St. Sabas (cf. Cyr. Scyth. Vita S. Sabas 32, ed. Schwartz 1939, p. 117). However, at the time the manuscripts were written, the monasteries in Syria were in a precarious condition, and many of them were destroyed (Nasrallah 1981, p. 80). Only a few monasteries in Syria demonstrably existed at that time, and Nasrallah mentions only two monasteries in Egypt that survived (Nasrallah 1981, p. 82). This hindered the intellectual exchange between these monasteries.

This explains the phenomenon of parallel translations of the same work at different monasteries, which leads to different Arabic versions of this work. Some of them were exchanged later so that the library of the monastery of St. Catherine on Mount Sinai also houses manuscripts or copies of manuscripts from Palestinian monasteries. It is thus not astonishing to find a Typikon tradition, which involves the Sinai monastery as well as Palestinian monasteries. The Sinai monastery recruited its monks not only from Egypt, but also from the realm of the patriarchate of Antioch and beyond, so it is also possible that some of them brought their Typikon tradition to the monastery.

This leads to the conclusion that the process of the Arabic translation of the Typikon was not a centralized process and that the patriarchs were not involved. Rather, the monasteries decided by themselves to translate the Byzantine liturgical books, to copy them, and to exchange them with other monasteries.

\section{Observations Regarding the Celebrated Worship}

\subsection{Multilingualism}

The process of Arabization raises several questions, among them the question of connection to Islamization (see Wasserstein 2006), the influence of the movement of Arabs outwards from the Arabian peninsula, or the impact of the coordinated translation of Greek literature into Arabic.

The Melkites, apparently, started to write in Arabic by the middle of the 9th century and to translate Christian texts (Leeming 2003, p. 240). However, translations of litur- 
gical texts started from the 13th century onwards, and no systematic translations of any liturgical books are not found before the 17th century. The process of Arabization developed in waves and was sometimes interrupted by stages of Re-Graecization. Up to the 13th century, the Melkites tended to use Greek or Syriac (Christian Palestinian Aramaic) in worship, maybe because people assumed a certain dignity of the established liturgical languages (Pahlitzsch 2006, p. 40) or because the language was part of their identity since the Melkites defined themselves also as "as-Suryānī" (Pahlitzsch 2006, p. 47). Arabic happened to be implemented because Greek was not understood any longer.

This multilingualism of the Melkites is reflected in worship and thus also in the Melkite manuscript tradition. At the large monasteries of Mar Saba in Jerusalem or St. Catherine of Mount Sinai, there were apparently monks from different origins who spoke different languages. Most scholars assume that they celebrated worship in linguistically separated communities, especially regarding the Liturgy of the Hours as well as the Liturgy of the Catechumens. However, the Divine Liturgy was celebrated together in Greek. This assumption is, however, based on accounts from Palestinian monasticism and may be wrong, but it helps to explain the number of horologia manuscripts in contrast to euchologia manuscripts (Galadza and van Vogelpoel 2019, p. 37). It also seems probable that Arabs attended services together with the Greek community and that their worship was bilingual in Arabic and Greek (Leeming 2003, p. 242).

The manuscripts reflect this bilingualism: Daniel Galadza and Alex C. J. Neroth van Vogelpoel described a Melkite manuscript giving the text of the Liturgy of St. John Chrysostom in Syriac letters but with many of the deacon's parts and the people's responses in Greek words in Syriac letters (see Galadza and van Vogelpoel 2019). They conclude that Greek text in Syriac letters was spoken in Greek and that the Divine Liturgy was thus celebrated in a bilingual mix of Greek and Syriac. The same is true for the Arabic Typikon manuscripts. The oldest one, Sin. arab. 265, describes an all-night-vigil in full, which is mostly Greek with the exception of some intercessions and the hint to an Arabic ad hoctranslation of the Bible (Lüstraeten 2017, p. 809). The other manuscripts also show the phenomenon of quoting Greek incipits in Arabic letters or in Arabic translation, leading to assumptions of their Greek or Arabic performance. ${ }^{3}$ In the long perspective, the Arabic Typikon manuscripts tend to quote more and more elements in Arabic than in their original language, thereby preferring the ordinary parts of the community as well as the parts of the deacon that are directed towards the community (Lüstraeten 2017, p. 810). Thus, it seems that the Arabization of Melkite worship started with the parts of the community or directed to the community, whereas the rest is preserved in the original language, leading to bilingual worship.

\subsection{The Bible Version}

Which Bible was used during worship? There are many different Arabic Bible versions in the manuscript tradition, especially since they are translated from different languages and different text types at different times and sometimes even from memory. ${ }^{4}$ Since Bible scholars were concentrating on the original text of the Bible, the Arabic Bible versions were not discussed for a long time. In the middle of the 19th century, the idea was discussed that the Arabic Bible is largely based on the Latin tradition (Schulthess 2012, p. 520), and in the 20th century, the focus of Arabic Bible studies was to find preIslamic Arabic translations in order to argue for the existence of fully Arabized Christians in Pre-Islamic times (Schulthess 2012, p. 522). A thorough investigation of the Arabic Bible started in 1980 with the works of Samīr $\mathrm{H}_{\mathrm{ali}} \mathrm{l}$ Samīr.

The most important contribution is the monograph of Hikmat Kashouh (2012) "The Arabic Versions of the Gospels. The Manuscripts and their Families", which he published in 2021. Kashouh limits his work to the gospels, he extracts eight test passages from more than two hundred manuscripts copied between the eighth and nineteenth centuries, compares them, and groups them. He also compares the different variants with Bibles in other languages to determine the respective original. The manuscripts are from different books, 
such as full Bibles as well as liturgical books like lectionaries. The concentration on samples was necessary to work with that many manuscripts, but unfortunately limits the validity of his conclusions.

Since in an article from Kashouh (2007) published a comparison of his manuscripts based on John 1:1 and John 1:18, I was able to compare the quotations of the Prologue to John as given per incipit in the Typikon manuscripts for the reading at the Easter service to the samples of Kashouh.

According to this, the translator of Sin. arab. 264 used the so-called "Alexandrinian Vulgate," the most widespread version of the Bible, a Bible that was based on a Syriac or a Greek original and then corrected against the Coptic version of the Bible (Kashouh 2012, p. 205). This version of the Bible goes back to the 10th century and became standard from the 13th century onwards, so that it is not surprising to find it here.

The identification is much harder for the other Typikon manuscripts: The related manuscript Mār Šw. 34 does not quote the incipit; at another incipit, the manuscript does not quote the verse from Matthew but the synoptic verse from Mark, which makes it impossible to compare the incipits to the samples provided by Kashouh. The oldest manuscript, Sin. arab. 265, does not quote incipits, and the manuscripts Sin. arab. 267, Sbath 73, and Said. 107 quote from a Syriac gospel. Regarding Sin. arab. 266, it is not possible to compare the Prologue to John but the incipits of the resurrection gospels; however, for comparison I could not use the samples of Kashouh but the wording of Sin. arab. 101, one of the oldest extant manuscripts of the "Alexandrinian Vulgate". Following this, Sin. arab. 266 does not quote the Alexandrinian Vulgate, but its wording shows a close connection to the established Byzantine Greek Gospel. Thus, it seems, that the resurrection gospels are direct translations from the liturgical book (Lüstraeten 2017, pp. 170-79).

For a further identification of the version of the Bible used, it is necessary to compare the quotes from the Psalms as given in the Typikon manuscripts. However, this requires a thorough study of the Arabic tradition of Psalms, which is still pending, as the research concentrated on the Gospel tradition so far.

\subsection{The Calendar of Saints and the Neo-Martyrs}

How did the Melkites treat their particular martyrs who were never commemorated in Byzantium? To distinguish the early martyrs who died during the persecutions in the time of the Roman Empire from the faithful Christians who suffered their martyrdom in later times, the term "neo-martyr" is applied. However, the term is unspecific: according to Constantin Simon (2006, pp. 100-1), there are four groups of "neo-martyrs", divided along their respective epoch:

- the Iconoclasm

- the Ottoman Empire

- the Roman Catholic or Protestant Rule and

- the Communist Regime.

In this division, he unfortunately overlooks those martyrs who died under the early Islamic rule, maybe because of his focus on Byzantium and Russia. ${ }^{5}$ Vaporis (2000, pp. 1-2), who focused his research on the "neo-martyrs" of the Ottoman Empire concluded that the rise of martyrdoms is in general a signal for the decline of a society (Vaporis 2000, p. 14), which was obviously the case, too, for those Christians under the rule of Islam.

In 2018, Christian Sahner published his monograph "Christian Martyrs under Islam. Religious Violence and the Making of the Muslim World", which was the first book concentrating on the Christian "neo-martyrs" under Islamic dominion. He analyses the hagiographical accounts of those martyrdoms with a focus on the social and juridical backgrounds. According to him, several elements of those hagiographical accounts do not need to be motifs but seem to reflect the reality of trial, torture and execution of Christians (Sahner 2018, p. 160). He reports that there was probably never broad-based persecution of Christians but episodes of religious violence in different regions at different times (Sahner 2018, p. 162). Usually, the Islamic states reacted to notifications of private individuals 
about conversions to Christianity (Sahner 2018, pp. 163-64), which was perceived by the rulers as apostasy from Islam or as blasphemy. Although those cases were handled with great care (Sahner 2018, p. 168), there was never a doubt about the Qur'àn enjoining death penalty as is said in Q 5:33:

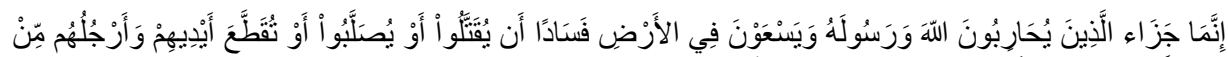

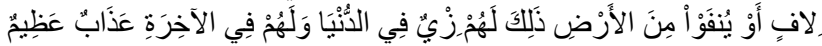

And the punishment of those who make war against 'Allah and his messenger and walk upon the earth with corruption will be that they are killed or crucified or have their hands and feet cut off on alternate sides or that they are exiled from the earth. This is for them the disgrace in the world and for them thereafter a heavy punishment.

Some of the "neo-martyrs" suffered exactly the punishments mentioned here (Sahner 2018, p. 171). Public executions had the function of stabilizing the ruling regime at a moment when non-Muslims were the large majority; they also forged boundaries between Christianity and Islam at a time of porous borders and intermingling (Sahner 2018, p. 161).

Probably the first occasion was under the reign of caliph 'Abd Al-Malik (685-705), who began to promote the new religion and the new language and to supersede Christianity. The measurements for the Islamic mission were successful, especially the settlement of Arab Muslims in the new provinces and the introduction of a tax per head for Christians and Jews so that although there was no systematic Islamization of the people, many of them converted to Islam. However, any Christian, who converted to Islam and afterwards converted back to Christianity had to fear a death penalty for apostasy and many of the Melkite "neo-martyrs" of this epoch are such "apostates", who converted unintentionally or through trickery to Islam but wished to remain Christians. The next occasion was as the power passed from the Umayyad to the Abbasid Caliphate and the new caliph, AlMansūur (754-775), forbid the public display of crosses on churches (Schick 1995, p. 163), the use of other languages than Arabic, the ringing of bells or the beating of woodclappers (Schick 1995, p. 166), etc. One of his successors, Hārūn Ar-Rašīd (786-809) continued this discrimination and during the civil war of the fourth fitna (809-813) between his sons, Christians fled to Cyprus or Byzantium.

It is thus not surprising that Christians who died during those attacks were considered martyrs in their respective communities and Sahner claims that most of the hagiographical accounts were written by Melkites and concludes that the Melkite Church lost their imperial support through the expansion of Islam and was thus in need to build up a new identity (Sahner 2014, p. 92; Sahner 2018, p. 200). The hagiographical accounts also served the function to discourage any Christian from considering converting to Islam.

However, in contrast to other Christian denominations, the Melkites included the new martyrs and the new hagiographical material into their Synaxarion, i.e., the calendar of saints that gives for each day the proper saints as well as short summaries of their lives to be read at liturgical assemblies. It needs to be distinguished on the one hand from the Mēnologion, which would be a pure calendar of saints and the Mēnaion, which would not contain the summaries of the saints' lives but the proper for each feast.

The calendar of saints of the Melkite Synaxarion was edited and analyzed by JosephMarie Sauget in his book "Premières Recherches sur l'Origine et les Caractéristiques des Synaxaires Melkites", which was published in 1969. In this investigation, Sauget compared 19 Melkite Synaxaria (distributed in 20 different manuscripts) of different ages, from the 11th to the 18th century (Sauget 1969, pp. 40-108), so it is obvious that these are Synaxaria of different stages of development. He explicitly excluded the first printed Melkite Synaxarion of Malātiyūs Karma (1612), since this was an Arabic translation of a Greek Byzantine liturgical book (Sauget 1969, p. 25). He tried to figure out the genesis of the sanctoral cycle and the presumed influences on it. Sauget found out that all analyzed Synaxaria copied and expanded the same archetype (Sauget 1969, p. 109) and that this original Synaxarion was a translation of a Byzantine Synaxarion, written in the 11th 
century (Sauget 1998, p. 178), similar to the Synaxarion of Codex Ambr. Grec. C 101 Sup. The differences between the different manuscripts of the Synaxarion result from later additions, e.g., of local saints or of feasts of other calendars, so the common structure of the different manuscripts is supposed to represent the primitive structure of the original Melkite Synaxarion (Sauget 1969, p. 109). Starting from that point, all manuscripts were enriched by the adoption of saints, and almost all of these manuscripts added Byzantine saints (Sauget 1969, pp. 170-71).

Furthermore, Sauget identifies two groups of manuscripts: a "primitive group", representing the original structure of the Melkite Synaxarion as given in the Greek original manuscript, and an "augmented group" of manuscripts that were enriched with further feasts of non-Byzantine origin. Comparing the manuscripts of the "augmented group" shows that there are some commemorations that appear in almost all manuscripts of this group and that cannot be traced back to a Byzantine influence, which Sauget identifies as

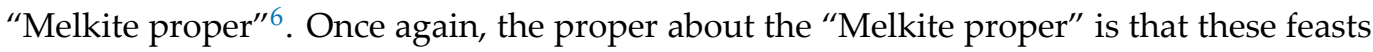
are mentioned in almost every manuscript of the Melkite Synaxarion despite being unknown to the Byzantine Synaxarion. The "Melkite proper" consists of 36 feasts (Sauget 1969, p. 179) ${ }^{7}$ :

- Abraam, the brigand (September 7th)

- Theodōros, the patriarch (September 24th)

- Basileios, the patriarch (September 25th)

- Abraam, the youth (October 6th)

- Nikolaos, the patriarch (October 8th)

- Iōannēs of Daylam (October 10th)

- Eustratios (October 17th)

- Ambakum (October 17th)

- Michaēl (October 17th)

- 63 martyrs of Jerusalem (October 22nd)

- dedication of Geōrg (November 3rd)

- $\quad$ Palladios (November 27th)

- translation of Iakōbos (December 1st)

- $\quad$ translation of Dēmētrios (December 2nd)

- Antōnios, the Qurayšì (December 24th)

- Iōannēes, the hesychast (January 8th)

- Maximos and Dometa (January 10th)

- Kyriakos (January 30th)

- Agathanos (February 7th)

- 'Abd al-Masīh (Christodulos) (March 9th)

- Agathōn (March 10th)

- Tamūn (March 25th)

- Stephanos, the Sabaite (April 2nd)

- Kopras and Patermuthios (April 7th)

- Ephraim (May 5th)

- Theoktiste (May 13th)

- Märtyrer of Mamilla (May 20th)

- Christophoros of Antioch (May 21st)

- Kyriakos of Jerusalem (May 21st)

- Michaēl in Alexandria (June 6th)

- $\quad$ Bišoy (July 2nd)

- Asia (July 15th)

- Michaēl, the Sabaite (July 19th)

- Theodōros of Edessa (July 19th)

- Barlaam (July 19th)

- Aiglōn (August 12th)

Ignace Dick summarized the list as follows. 
The saints proper for the Melkite Synaxaria are mainly patriarchs of Antioch of the 10 th and 11th centuries, monks from the 9th to 10th century, and martyrs killed by the Muslims. $^{8}$

Those martyrs killed by the Muslims are:

- $\quad$ The 63 martyrs of Jerusalem (October 22nd), who were crucified around the year 724 (Sauget 1969, pp. 310-11).

- $\quad$ Antōnios, the Qurayšì (December 24th), who was martyred in Raqqa in the year 799 because he worked a miracle with an icon of Theodore of Damascus (Sauget 1969, p. 332; Simon 2006, p. 121).

- Kyriakos (January 30th), who was beheaded (Sauget 1969, p. 343).

- Abd al-Masīh.(Christodulos) (March 9th), who was a higoumen of the Sinai monastery in the early 8th century (Sauget 1969, p. 366).

- $\quad$ Ephraim (May 5th) (Dick 1994, p. 134).

- Christophoros of Antioch (May 21st) (Sauget 1969, p. 380).

- $\quad$ Michaēl, the Sabaite (July 19th).

In some manuscripts, there are more commemorations of "neo-martyrs" and some of the saints of this list could not be identified precisely (e.g., Agathōn, who is commemorated on March 10th), so the number of "neo-martyrs" in the "Melkite proper" is maybe higher. Sauget suggests that these new commemorations - and by this the commemorations of the "neo-martyrs" - were introduced into the Melkite Synaxarion because of a Melkite liturgical reform (Sauget 1969, p. 176).

Among the new finds of Mount Sinai was the manuscript Sin. syr. M52N (Philothée 2008, pp. 501-20), which consists of two units of different dimensions, of which the first one contains a calendar of saints from October to September, which was further investigated in an essay by André Binggeli. In fact, it is a simple list that indicates for each day the name of the saint, without further information on his life or on the proper texts for this feast. Binggeli identifies this as an ancient Melkite calendar and observed that it stops at Maximos Confessor, who died in 662, so that several saints of the time after the spread of Islam are missing (Binggeli 2010, pp. 190-91) - with the exception of three Palestinian "neo-martyrs" (Binggeli 2010, p. 192):

- $\quad$ Bacchos (December 16th and April 11th)

- Christophoros (May 13th)

- Antōnios (December 29th)

All of them are "neo-martyrs" of the time of early Islam: Bacchos and Christophoros were both found guilty of apostasy and therefore died in the 8th century (Binggeli 2010, p. 191). Additionally, Antōnios is already known from the "Melkite proper" of the Synaxarion. Although this calendar does not confirm the feasts of the "Melkite proper", it confirmsaccording to Binggeli-that the Melkites introduced new feasts of martyrs before the 10th century (Binggeli 2010, p. 193). In fact, they are already designated as "new martyrs" in the Syriac text (ס ) - a term that can also be found in the Greek hagiographical

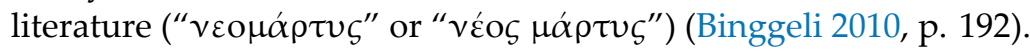

Now, regarding the Typikon manuscripts, it is striking that no manuscript presupposes the same liturgical calendar. When comparing the liturgical calendar of the Melkite Synaxarion to the liturgical calendar of the several Melkite Typika, one has to respect that the latter usually only indicates the commemorations for which proper liturgical texts exist, whereas the Synaxarion usually indicates all commemorations of a day. This could explain minor differences and missing commemorations. However, the result is surprising: of the commemorations of the "neo-martyrs" that are given in the Melkite Synaxarion or in the ancient Melkite Mēnologion, none is taken up in any of the Arabic Typikon manuscripts.

Regarding the Melkite Synaxarion, one notes that the feasts of the "Melkite proper" are largely ignored in the Arabic Typikon manuscripts. There are only three exceptions:

- The dedication of Geōrg (November 3rd) is witnessed in all Arabic Typikon manuscripts but the oldest one. 
- The miracle of Michaēl in Alexandria (June 6th) is witnessed in one Greek-Arabic Typikon manuscript.

- Theodōros of Edessa (July 19th) is witnessed in the same manuscript.

However, one has to state that from the "Melkite proper" that consists of 36 commemorations, only three feasts are mentioned in some of the Arabic Typikon manuscripts, so the "Melkite proper" of the Melkite Synaxarion was practically not incorporated into the Melkite Typikon. The same is true for the commemorations of the Melkite Mēnologion: None of the "neo-martyrs" is mentioned in the Arabic Typikon manuscripts.

One reason could be the age of the respective tradition: if the reform that was presumed in the Synaxarion tradition took place after the beginning of the Typikon tradition, the earliest Typikon manuscripts could not have copied it. Furthermore, it seems plausible to assume that a Typikon tradition would develop independently of a Synaxarion tradition. The interdependencies between the different Typikon manuscripts show that the regular way of the genesis of a new Typikon manuscript was to copy and adjust an older Typikon manuscript. However, how can we think about an authority that was able to introduce a "Melkite proper" of 36 commemorations into the Synaxarion but not into the Typikon, even though both books were copied in the same scriptoria of the same monasteries?

Another solution is that there was maybe no reform and no "Melkite proper" but a pure coincidence that Sauget found a large "augmented group" that in fact could have belonged to a small community and did not play a significant role in the development of the Melkite rite. It is also possible that there was a liturgical reform that was contested and that the Arabic Typika witnesses the tendency of refusal of that reform for the purpose of conserving the more ancient-and thus the more Melkite-practice (Lüstraeten 2017, p. 519). In fact, the Typikon manuscripts were not as widespread as the Synaxarion manuscripts, and in each group of the Arabic Typikon manuscripts, there is at least one manuscript that was copied at the Sinai monastery that could have served in multiplicating a conservative Arabic Typikon tradition. The argument against this is that the deviations of the Arabic Typikon from the Melkite Synaxarion are usually identified as adjustment to the Byzantine Rite. However, both ideas cannot explain why the "neo-martyrs" - which are apparently important for the identity of the Melkites - are ignored.

A third solution is to claim the reform and the addition of the "Melkite proper" solely for the Synaxarion tradition, because of the different purposes of the books. Whereas the Synaxarion keeps the records of all the saints that contribute to the identity of a group, the Typikon gives directions for the celebrations of the different days and is thus limited to the shape of the group's worship.

Additionally, this may be the key for understanding the Arabic Typikon: of course the "neo-martyrs" are important for the identity of the Melkites as Melkites, but they are a hindrance in the self-definition of the Melkites as Byzantine Orthodox, since the Melkite "neo-martyrs" are not commemorated in the Constantinopolitan Synaxarion and hence not in Greek Byzantine worship. Thus, in commemorating Melkite saints from outside Byzantium in worship, one separates from the Byzantine Church and Empire. The exclusion of the "neo-martyrs" needs not be an intended consequence-in copying and translating Byzantine Typika with the aim of adjusting their own rite to the Byzantine Rite, the Melkite "neo-martyrs" could have been omitted (Sahner 2018, pp. 249-50).

There is one more observation: in commemorating the "neo-martyrs", the deeds of the Islamic aggressors are also commemorated, which could aggravate the interreligious life in the Islamic Empire. This is corroborated by the fact that not only the Melkite "neomartyrs" are ignored but so are other commemorations such as the victory against the Saracenes on August 16th, which is mentioned in the Melkite Synaxarion as well as in the Constantinopolitanian Synaxarion but not in the Melkite Typikon. The omission of historic conflicts could have served to prevent suspicion and new conflicts (Sahner 2018, p. 249). 


\section{Who Was Affected?}

In his monumental work on the Melkite Church, Nasrallah admits that for the time of Mamlūk dominion, when the Typikon manuscripts were written, it is hard to reconstruct the lists of patriarchs, since most of them did not bequeath written testimonials to us (Nasrallah 1981, p. 45). Some of the patriarchs resided in exile at Constantinople and were elected there; we know little about bishops among the Melkites and due to the sources, Nasrallah does not even try to reconstruct the situation of the individual believers and the parishes.

In the beginnings of Islam up to the 9th century, Christianity and Islam were intermingled and borders between the two groups were porous (Penn 2015, p. 145). Apparently, it was quite common for Christians and Muslims to partake in the same rituals (Penn 2015, p. 166), and it seems that there was no sensible difference between Christians and Muslims alike. This is also due to the circumstance, that most of the people who would have called themselves "Christians" were baptized and attended worship on occasion, but also had no problems with magic or syncretistic rituals such as charms or necromancy and did not care much about questions of doctrine (Tannous 2018, p. 227). In his monograph “The Making of the Middle East. Religion, Society, and Simple Believers" from 2018, Jack Tannous argues that the majority of "simple Christians" did not know about theological issues such as incarnation or trinity, which from our point of view seem divisive between Islam and Christianity (Tannous 2018, p. 235). Since there were regions without priests or monks, there would have been no one to provide religious education, so the differences between Islam and Christianity were blurred.

The insufficient religious education was advantageous for religious conversions from Islam to Christianity, insomuch as there were no theological objections against Islam, but reasons such as material benefits, the chance of status and power, or simply a less regulated way of life (Tannous 2018, pp. 312-13). Tannous points to the circumstance that none of the contemporary authors write about theological reasons for conversion. Furthermore, it is obvious that there were fiscal benefits for Muslims, like for example tax reliefs. There were apparently conversions from Christianity to Islam, but also-as the case with the "neomartyrs" shows-also re-conversions from Islam to Christianity (Tannous 2018, p. 334). This corroborates the assumption that conversions did not happen because of doctrine.

Furthermore, Tannous lists Christian ritual elements that were widespread among Christians as well as Muslims, such as the use of the consecrated Eucharist within rituals (Tannous 2018, pp. 371-74), the use of the name of Jesus Christ (Tannous 2018, pp. 374-75), baptism (Tannous 2018, p. 375-76), the application of the cross or the sign of the cross (Tannous 2018, pp. 376-80), or Christian relics (Hasluck 1929, pp. 36-37). Overall, this suggests an ideology of religious tolerance, at least among the "simple believers" of Christianity and Islam regarding Christian ritual life, which did not affect kinds of tolerance regarding doctrine or worship itsel, because they were foreign to them (Tannous 2018, p. 396). There was, thus, up to the 9th century no sharp distinction between being Christianity and being Islam.

Considering all of this, we need to ask for the "simple believers" among the Melkites: we do not know about the parishes and about the liturgy that was celebrated there, but we may assume that if there were priests, they probably never knew about manuscripts of Arabic Typika that circulated among the Melkite monasteries. Thus, any findings regarding the Byzantinization of the Melkites focus on the monasteries and are maybe not representative of all the Christians who would have defined themselves as "Melkite".

\section{Conclusions}

Byzantinization and Arabization appear as parallel phenomena. Although Byzantinization started earlier and although both processes developed non-linearly and in waves, they both ended with the new translations by Malātiyūs Karma. which also set an end to the tradition of manuscripts. The time before, when Byzantinization and Arabization occurred, both processes were not centrally regulated but individual and parallel processes 
at the monasteries - the most important one among them the monastery of St. Catherine on Mount Sinai. The manuscripts which are preserved there-even today-are testimonials for a liturgical development as well as for the definition of a Melkite identity between other Christian denominations on the one hand and Islam on the other hand.

The Typikon manuscripts are documents to both processes: they are originally Byzantine liturgical books that were translated to Arabic, adapted, and expanded. They show the bilingualism of Melkite worship at different stages of history, and they regulate the use of liturgical books that became-as shown for the Gospel-more and more standardized. The search for an own identity becomes manifest in the case of the "neo-martyrs" and the Typika's silence about them.

After all, we have to be careful about the coverage of the manuscripts. They were written at monasteries, copied at monasteries, and exchanged between monasteries - apparently without affecting the worship of the individual believer.

Funding: This research received no external funding.

Institutional Review Board Statement: Not applicable.

Informed Consent Statement: Not applicable.

Data Availability Statement: Not applicable.

Conflicts of Interest: The author declares no conflict of interest.

\section{Notes}

$1 \quad$ All translations provided in this paper are mine.

2 According to Nasrallah (1981, p. 150), this is a mistake and should be pronounced Aš-širotoniya, meaning the ordination, and that he wrote a commentary about it.

3 This is, of course, only a valid assumption if one can assume that the manuscripts were written for a liturgical purpose. The basic assumption that Syriac incipits indicate Syriac prayers is challenged by Galadza and van Vogelpoel (2019, p. 48).

4 Arthur Stanley Tritton (1933, p. 857) shows this for Theodor Abū Qurra.

5 Although Simon mentions "in addition" the martyrs of the Coptic Church, among them particularly those who died under Islamic persecutions (114), even today there are Coptic Christians in Egypt who are killed as martyrs, but they are usually not commemorated for political reasons (115). He also refers to the Christian martyrs who suffered their martyrdom under Soviet rule; some of them are canonized now (145).

6 Originally: "propre melkite" (Sauget 1998, p. 181).

7 The spelling here corresponds to the presumed Greek spelling.

8 Originally: "Les saints propres aux synaxaires melkites sont surtout des patriarches d'Antioche des 10e-11e siècles, des moines des 9e-10e siècles et des martyrs tués par les Musulmans." (Dick 1994, p. 133).

\section{References}

'Aț̣ya, 'Az̄̄z Sūryāl. 1970. Al-Fahāris at-tahlīlīya li-mahtūtāt Tẹur Sīnā al-arabīya. Alexandria: Munša'at al-Ma ārif.

Binggeli, André. 2010. Un Ancien Calendrier Melkite de Jérusalem (Sinaï Syr. M25N). In Sur les Pas des Araméens Chrétiens: Mélanges Offerts à Alain Desreumaux. Edited by Françoise Briquel-Chatonnet. Cahiers d'Études Syriaques 1. Paris: Geuthner, pp. 181-94.

Dick, Ignace. 1994. Les Melkites: Grecs-Orthodoxes et Grecs-Catholiques des Patriarcats d'Antioche, d'Alexandrie et de Jérusalem. Fils d'Abraham. Paris: Brepols.

Galadza, Daniel. 2018. Liturgy and Byzantinization in Jerusalem. Oxford: Oxford University Press.

Galadza, Daniel, and Alex C. J. Neroth van Vogelpoel. 2019. Multilingualism in the Divine Liturgy of St. John Chrysostom among the Melkites. Aram 31: 35-50.

Ghoneim, Hanna. 2010. Der Byzantinische Bischofsweiheritus in Der Melkitischen Kirche: Eine Liturgiegeschichtliche Vergleichende Untersuchung. Wien: University Library of Vienna.

Hasluck, Frederick William. 1929. Christianity and Islam under the Sultans. Oxford: Clarendon Press, vol. II.

Hirschfeld, Yizhar. 2006. The Monasteries of Palestine in the Byzantine Period. In Christians and Christianity in the Holy Land: From the Origins to the Latin Kingdoms. Edited by Ora Limor and Guy G. Stroumsa. Cultural Encounters in Late Antiquity and the Middle

Ages 5. Turnhout: Brepols, pp. 401-19. 


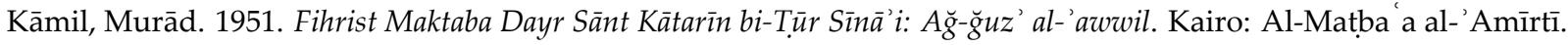

Kashouh, Hikmat. 2007. The Arabic Versions of the Gospels: A Case Study of John 1.1 and 1.18. In The Bible in Arab Christianity. Edited by David Thomas. History of Christian-Muslim relations 6. Leiden: Brill, pp. 9-36.

Kashouh, Hikmat. 2012. The Arabic Versions of the Gospels: The Manuscripts and Their Families. Arbeiten zur Neutestamentlichen Textforschung 42. Berlin: De Gruyter.

Leeming, Kate. 2003. The Adoption of Arabic as a Liturgical Language by the Palestinian Melkites. Aram 15: 239-46. [CrossRef]

Lüstraeten, Martin. 2017. Die handschriftlichen arabischen Übersetzungen des byzantinischen Typikons: Zeugen der Arabisierung und Byzantisierung der melkitischen Liturgie. Jerusalemer Theologisches Forum 31. Münster: Aschendorff.

Meïmarēs, Iōannēs E. 1985. Katalogos tōn Neōn Arabikōn Cheirographōn tēs Hieras Monēs Hagias Aikaterinēs tu Orus Sina. Athen: Ethnikon Hidryma Ereunōn.

Mouawad, Ray Jabre. 2002. Les Mystérieux Monastères de Keftūn au Liban à l'Époque Médiévale (XIIe-XIIIe siècle): Maronite et/puis Melkite? Tempora 12-13: 95-113.

Nasrallah, Joseph. 1979. Histoire du Mouvement Littéraire dans l'Église Melchite du Ve au XXe Siècle: Contribution à l'Étude de la Littérature Arabe Chrétienne. Vol. IV Période Ottomane 1516-1900. Tome 1: 1516-1724. Louvain: Peeters.

Nasrallah, Joseph. 1981. Histoire du Mouvement Littéraire dans l'Église Melchite du Ve au XXe siècle: Contribution à l'Étude de la Littérature Arabe Chrétienne. Vol. III. T. 2 (1250-1516). Louvain: Peeters.

Nasrallah, Joseph. 1983. Histoire du Mouvement Littéraire dans l'Église Melchite du Ve au XXe siècle: Contribution à l'Étude de la Littérature Arabe Chrétienne. Vol. III T.1 (969-1250). Louvain: Peeters.

Nasrallah, Joseph. 1987. Histoire du Mouvement Littéraire dans l'Église Melchite du Ve au XXe siècle: Contribution à l'Étude de la Littérature Arabe Chrétienne. Vol. II. Tome 2: 750-Xe s. Louvain: Peeters.

Nasrallah, Joseph. 1989. Histoire du Mouvement Littéraire dans l'Église Melchite du Ve au XXe siècle: Contribution à l'Étude de la Littérature Arabe Chrétienne. Vol. IV-Époque Ottomane 1516-1900. Tome 2: 1724-1800. Louvain: Peeters.

Nasrallah, Joseph. 1996. Histoire du Mouvement Littéraire dans l'Église Melchite du Ve au XXe Siècle: Contribution à l'Étude de la Littérature Arabe Chrétienne. Vol. II. Tome 1 (634-750). Damaskus: Éditions de l'Institut Français de Damas.

Nasrallah, Joseph, and Rachid Haddad. 2016. Histoire du Mouvement Littéraire de l'Église Melchite du Ve au XIXe siècle: (Vol I: Période Byzantine 451-634). Beirut: Ifpo.

Pahlitzsch, Johannes. 2006. Griechisch-Syrisch-Arabisch: Zum Verhältnis von Liturgie- und Umgangssprache bei den Melkiten Palästinas im 12. und 13. Jahrhundert. In Language of Religion-Language of the People: Medieval Judaism, Christianity and Islam. Edited by Ernst Bremer, Jörg Jarnut, Michael Richter and David J. Wasserstein. Mittelalterstudien des Instituts zur Interdisziplinären Erforschung des Mittelalters und seines Nachwirkens, Paderborn 11. München: Wilhelm Fink Verlag, pp. $37-47$.

Penn, Michael Philip. 2015. Envisioning Islam: Syriac Christians and the Early Muslim World. Divinations. Rereading Late ancient Religion. Philadelphia: University of Pennsylvania Press.

Philothée, du Sinaï. 2008. Nouveaux Manuscrits Syriaques du Sinaï. Athen: Fondation du Mont Sinaï.

Sahner, Christian C. 2014. Old Martyrs, New Martyrs and the Coming of Islam: Writing Hagiography after the Conquests. In Cultures in Motion: Studies in the Medieval and Early Modern Periods. Edited by Adam Izdebski and Damian Jasiński. Byzantina et Slavica Cracoviensia 8. Cracow: Jagiellonian University Press, pp. 89-112.

Sahner, Christian C. 2018. Christian Martyrs under Islam: Religious Violence and the Making of the Muslim World. Princeton: Princeton University Press.

Sauget, Joseph-Marie. 1969. Premières Recherches sur l'Origine et les Caractéristiques des Synaxaires Melkites: (XIe-XVIIe siècles). Subsidia Hagiographica 45. Brüssel: Société des Bollandistes.

Sauget, Joseph-Marie. 1998. Littératures et manuscrits des chrétientés syriaques et arabes. Vatikan: Bibliotheca Apostolica Vaticana.

Sbath, Paul. 1928. Bibliothèque de Manuscrits Paul Sbath: Tome I. Kairo: Friedrich.

Schick, Robert. 1995. The Christian Communities of Palestine from Byzantine to Islamic Rule: A Historical and Archaeological Study. Princeton: Darwin Press.

Schulthess, Sara. 2012. Die arabischen Handschriften des Neuen Testaments in der zeitgenössischen Forschung: Ein Überblick. Early Christianity 3: 518-39.

Schwartz, Eduard. 1939. Kyrillos von Skythopolis. Texte und Untersuchungen zur Geschichte der altchristlichen Literatur 49.2. Leipzig: J.C. Hinrichs.

Simon, Constantin. 2006. New Martyrs. Studi sull'Oriente Cristiano 10: 99-192.

Taft, Robert Francis. 2010. Worship on Sinai in the First Christian Millenium: Glimpses of a Lost World. In Approaching the Holy Mountain: Art and Liturgy at St. Catherine's Monastery in the Sinai. Edited by Sharon E. J. Gerstel and Robert S. Nelson. Cursor Mundi 11. Turnhout: Brepols, pp. 143-77.

Tannous, Jack. 2018. The Making of the Medieval Middle East: Religion, Society, and Simple Believers. Princeton: Princeton University Press. 
Treiger, Alexander. 2014. Unpublished Texts from the Arab Orthodox Tradition: (1): On the Origin of the Term "Melkite" and on the Destruction of the Maryamiyya Cathedral in Damascus. Chronos 29: 7-37. [CrossRef]

Tritton, Arthur Stanley. 1933. The Bible Text of Theodore Abu Kurra. Journal of Theological Studies 34: 52-54. [CrossRef]

Vaporis, Nomikos Michael. 2000. Witnesses for Christ: Orthodox Christian Neomartyrs of the Ottoman Period 1437-I860. Crestwood: St. Vladimir's Seminary Press.

Wasserstein, David J. 2006. Language and Prayer among Muslims, Christians and Jews in the Early Islamic World. In Language of Religion-Language of the People: Medieval Judaism, Christianity and Islam. Edited by Ernst Bremer, Jörg Jarnut, Michael Richter and David J. Wasserstein. Mittelalterstudien des Instituts zur Interdisziplinären Erforschung des Mittelalters und seines Nachwirkens, Paderborn 11. München: Wilhelm Fink Verlag, pp. 49-59. 